\title{
Book Review: Bad Blood-Secrets and Lies in a Silicon Valley Startup
}

\author{
Emeril Santander ${ }^{1,2}$ \\ ${ }^{1}$ Faculty of Medicine, University of Ottawa, Ontario, Canada \\ ${ }^{2}$ Newborn Screening Ontario, Children's Hospital of Eastern Ontario, Ontario, Canada
}

\section{ABSTRACT}

This book review appraises John Carreyrou's non-fiction book Bad Blood. The text provides penetrating insights on Theranos, an American laboratory diagnostics company that promised to revolutionize laboratory medicine. The author's award-winning prose relays the events leading to the eventual discovery of fraud at Theranos as well as the subsequent collapse of the company. The book can be faulted for being unripe. Publication prior to a full resolution to the Theranos affair precludes analysis of the longerterm impacts of this fraud. Notwithstanding, Bad Blood's imperfect timing, the book remains a seminal text amidst journalistic chronicles of medical innovation gone wrong.

\section{RÉSUMÉ}

Cette critique littéraire évalue le livre non-fiction de John Carreyrou « Bad Blood ». Le texte donne un aperçu pénétrant surTheranos, une compagnie américaine de diagnostics de laboratoire, qui promet de révolutionner la médecine laboratoire. La prose primée de l'auteur raconte les évènements menant à la découverte éventuelle de la fraude à Theranos, ainsi que le collapse subséquent de la compagnie. Ce livre peut être critiqué pour être inachevé. Sa publication avant la résolution complète de l'affaire Theranos empêche l'analyse des impacts à longue durée de cette fraude. Néanmoins le choix de moment imparfait de "Bad Blood », le livre reste un texte séminal entre les chroniques journalistiques d'innovations médicales mal tournées.

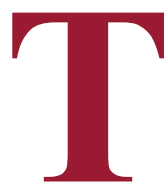

he seductive allure of medical innovation has been used successfully throughout time by people seeking to conceal unethical or even criminal acts. John Carreyrou's non-fiction book Bad Blood - Secrets and Lies in a Silicon Valley Startup (1) offers readers a comprehensive journalistic exposé of Theranos, a now-defunct laboratory diagnostics company formerly based in Palo Alto, California. This company, established in 2003 by former Stanford University student Elizabeth Holmes at age 19 , purported to offer a broad range of clinical diagnostic tests performed on a futuristic device using capillary blood from the fingertip. In a radical departure from conventional tests requiring full tubes of drawn blood, Elizabeth Holmes rose to fame by claiming her fear of needles drove her and her team to pioneer several advances in robotics and clinical chemistry. These alleged developments allowed Theranos to offer revolutionary tests on only microlitres of blood using next-generation assays. Theranos affirmed this was all possible without sacrificing any diagnostic accuracy but never adduced this claim in the medical literature, citing a need to protect proprietary secrets. An effective storyteller, Carreyrou begins by providing the reader with insight into company founder
Elizabeth Holmes' early life. In a relatively brief 299 pages, the author then details how Holmes' alleged innovations would eventually be revealed, over a decade later, to be consummate fantasy. Theranos' fingertip tests are presently thought to have been an elaborate fabrication crafted primarily in service of Holmes' pursuit of wealth and recognition. Media reports suggest certain Theranos tests were ultimately generated using traditional assays performed on equipment procured from conventional device vendors. Less fortunate patients had their results derived using unreliable prototypes of Theranos' own technology. Written in an easy-reading popular style, Bad Blood concludes by detailing the early stages of Theranos' spectacular collapse following methodological scrutiny from experts in pathology and clinical laboratory medicine, as well as regulatory enforcement from the United States Department of Health and Human Services.

Drawing mainly from interviews of former Theranos staff, collaborators and other closely-related primary sources, John Carreyrou emphasizes the day-to-day interactions that underpinned Holmes' deception of investors, media, physicians, regulators and vulnerable patients alike. Against

Keywords: Health Technology Fraud; Laboratory Regulation; Diagnostic Accuracy; Assay Development 
the backdrop of a scientific community intent on minimizing the role of individual personality traits or interpersonal dynamics on the trajectory of scientific discovery, Carreyrou expertly holds the scientific reader's attention to a specific true account of a young and charismatic charlatan who leveraged personal qualities to circumvent, if briefly, our esteemed process of vetted medical discovery. In several passages, Carreyrou vividly recounts Holmes' hypnotic voice, entrancing gaze, and self-assured demeanor as she misled scientificallyilliterate Silicon Valley investors seeking to profit from Theranos' meteoric rise. The author effectively relays how the superficial charm, aura of success and particularized bravado of Holmes and her associates kept inquisitive scientists, physicians and regulators away from Theranos headquarters for several years. Major pharmacy chains in the United States agreed to distribute Theranos tests based entirely on Holmes outstanding salesmanship and without any published validation studies. Inescapable for the medical audience is the sub-textual implication that Holmes' seemingly-innocuous idiosyncrasies sufficed to pervert the regular course of peerreviewed medical innovation and facilitated patient harm from faulty laboratory tests. Reading between the lines, Bad Blood also places a heavy burden on the shoulders of the physician or medical scientist: if a teen Stanford dropout can execute a complex fraud under the guise of medical innovation, what role will legitimate medical innovators have to play in ensuring that scientific discovery is not subverted in a manner that causes people harm?

Carreyrou's strict adherence to fact-based reporting will permit readers to form their own answer to this question as well as arrive at their own conclusions when determining what exactly went wrong within Theranos. From strikingly detailed reconstructions of the contorted sequence of events leading to Theranos' downfall, the reader will emerge with several possible loci on which to plausibly rest blame. It is possible that Silicon Valley itself is culpable; an innovation-driven culture that wantonly prioritizes technological innovation over patient safety is a clear path to disaster. Perhaps the media played a role. Carreyrou holds a magnifying glass to Holmes' depictions in popular outlets, whose content creators eagerly heralded Holmes as the archetypal manifestation of women's success in Silicon Valley's predominantly male environment. Holmes' ascent to renown fit neatly within prevailing social movements promoting women's achievements in Science, Technology, Engineering and Medicine and those fostering overdue gender equality within these same fields of endeavour.
Lastly, it would also be possible to conclude that there is a fundamental flaw with the overall conduct and regulation of medical innovation. Although eventually subject to scientific scrutiny and regulatory control, North American medical scientists and regulators spared Theranos from rigorous methodological assessment for more than ten years as the numbers of harmed patients continued to grow at alarming rates.

Bad Blood's cardinal limitation is prematurity. The book was concluded too soon, and any sensations of incomplete resolution felt by readers as the book draws to a close are entirely justified. The book's early publication precluded a complete understanding of the criminal outcomes of Elizabeth Homes' wire fraud trial, which remains underway. A complete account of the harms attributable to Theranos' defective tests is similarly unavailable. There is reason to believe these harms may be significant and numerous; Theranos'battery of offerings included tests used to dose drugs with narrow therapeutic indices, such as prothrombin time. Theranos patients have also reported receiving inaccurate results of endocrine function, including one patient whose severely elevated estrogen led her physician to believe her breast cancer may have returned. Finally, the book's swift publication prevented a complete analysis of Theranos' long-term impacts on the broader field of laboratory diagnostic medicine. Prior to collapse, Theranos had successfully lobbied legislators in Arizona to legalize patientdirect ordering of any diagnostic test offered by any clinical laboratory in the state without the involvement of a licensed primary healthcare provider. Ominously, this law remains in effect today despite the revelation that for many Theranos patients who received erroneous results, it was primary providers who ordered retests and in doing so stymied the cascade of patient harms that might otherwise have followed.

Above all else, the story of Theranos and Elizabeth Holmes forces the medico-scientific community to confront a difficult reality: In our new millennium, which presumably symbolizes the cumulative pinnacle of human achievement, it remains possible to perpetrate health-technological fraud while entirely concealed under the lustrous guise of innovative medicine.

\section{REFERENCES}

1. Carreyrou J. Bad Blood - Secrets and Lies in a Silicon Valley Startup. New York: Alfred A. Knopf, Inc.; 2018. 339 p. 